\title{
Cutting Deeper: U.S. Newspapers Wipeout Jobs and Alter Career Identities
}

\author{
Scott Reinardy ${ }^{a}$ and Lawrie Zion ${ }^{b}$ \\ ${ }^{a}$ School of Journalism and Mass Communications, University of Kansas, Lawrence, KS, USA; ${ }^{b}$ Department of \\ Journalism, La Trobe University, Melbourne, Australia
}

\begin{abstract}
Modeled on the "New Beats: A study of Australian Journalism Redundancies" project (2014-17), the purpose of this study was to gather data to examine how forced career change among U.S. newspaper journalists has affected their employment, professional identities, financial situations and perceptions of newspaper journalism. Drawing from a sample of about 350 former and current U.S. newspaper journalists who had lost their jobs, $47 \%$ said the career change did not affect their professional identity. Meanwhile, $36 \%$ still identify themselves as journalists, although many have not worked in their traditional newspaper job for several years. Similarities between this study and those conducted by the New Beats team include: About 30\% of those who left newspapers returned to journalism jobs; the most common new career for the departed was in media communications or marketing; and Australian journalists and American journalists demonstrated a breadth of positive and negative emotions after leaving their media jobs. A common finding between this study and the Australian parent study is that journalists are actively negotiating their professional identity at a profoundly challenging moment, and that despite the role of structural forces, journalists are retaining at least some agency in how they define themselves.
\end{abstract}

\section{KEYWORDS}

Newspaper journalists; job loss; professional identity; New Beats; U.S. newspapers; Re-employment

There is pleasure in work. Freud (1930) contends that work, done willfully, "affords particular satisfaction" (p. 35). Price, Friedland, and Vinokur (1998) wrote: "Freud (1961) argued that the two great wellsprings of mental health are love and work" (p. 303). So, what occurs when a person loses a job he or she loves?

Financial hardship is an obvious implication of job loss but certainly not the only consequence. Social status (Ezzy 1993) friendships (Bolton and Oatley 1987), role of family provider (Thoits 1991) and personal identity and self-esteem (Price, Friedland, and Vinokur 1998) are at risk following a job loss. Coping with financial hardship and efforts to find re-employment can introduce household instability and alter relationships (Conger et al. 1990; Menaghan 1991; Price, Friedland, and Vinokur 1998). Price, Friedland, and Vinokur (1998) wrote: "These identity interruptions are stressful, and the key to preventing their negative consequences is to allow a new identity to be affirmed" (p. 309). 
Greg Halling faced an identity crisis when he was laid off as editor of the Odgen (Utah) Standard-Examiner in May 2018. His digital-first, community-first newsroom initiative had transformed the small daily newspaper into an award-winning media outlet. But after purchasing the newspaper in April 2018, West Virginia-based Ogden Newspapers eliminated 21 positions at the Standard-Examiner, including five in the newsroom. Halling was among the newsroom cuts. Weeks after the layoffs, it was announced that the Standard-Examiner was among the top award winners at the Utah Society of Professional Journalists competition (Standard-Examiner staff 2018).

It was the second time the 59-year-old Halling lost his job in a newspaper-wide cut. More than three years earlier, Halling was laid off from the Elkhart (Indiana) Truth after eight years of employment. As Elkhart's editor, Halling also had converted the newsroom to a digital-first, community-first, award-winning news operation before losing his job. Following the layoffs, when asked about his work, Halling still said he was an editor and journalist, but admitted his sense of identity was challenged (Halling, personal communication, September 12, 2018).

Halling is one of thousands of U.S. newspaper journalists who have left newsrooms in the past decade. In an analysis of the Bureau of Labor Statistics Occupational Employment Statistics survey data, the Pew Research Center reported that U.S. newsroom employment, which included newspapers, radio, broadcast television, cable and other information services, declined 25\% from 2008 to 2018. Among newsrooms, newspapers had experienced the most devastating cuts - a 45\% decrease during the decade, from about 71,000-39,000 (Grieco 2018).

For newspaper newsroom survivors of layoffs and buyouts, the cuts created an environment where work demands were dramatically compounded, causing an increase in burnout and a decrease in job satisfaction (Reinardy 2017). Journalists who no longer worked in newspapers faced a different set of stressors. Some opted for retirement, while others left the industry altogether. Along with drastic career change comes a loss or transformation of work identity.

The purpose of this study is to examine how job loss and possibly career change among U.S. newspaper journalists has affected their professional identity and perceptions of newspaper journalism. Drawing from a sample of about 350 former and current U.S. newspaper journalists who had lost their jobs, the study will specifically examine the perceptions of those who returned to newspapers following a departure and those who changed careers altogether.

This study will build upon previous work conducted by New Beats: A Study of Australian Journalism Redundancies. The 2014 survey instrument developed by New Beats (Zion et al. 2016) was utilized in this study to examine work identity issues and the perception of newspaper work among U.S. journalists. New Beats is a joint industry-academic research project established in 2013 and funded by the Australian Research Council to explore the fate of journalists who had been laid off (Zion et al. 2016).

\section{Literature Review}

During the past decade, a growing body of research has investigated the impact of rapidly unraveling changes in news media industries to emotional wellbeing, working lives and professional identities of journalists. Studies have focused both on the survivors of 
newsroom layoffs, and on those who took buyouts or redundancies - a term that refers to jobs that are terminated with compulsory termination payments made to the employee. The increasing attention paid to the aftermath of careers disrupted by the downsizing of professional journalists because of the collapse of the classified advertising revenue model, and, more recently, the migration of online advertising revenue to Google and Facebook (Letts 2016), coincides with broader inquiries into the causes and consequences of the increasing precarity of work in the early twenty-first century. Nowadays, terms such as "digital disruption," and the "gig economy" have become embedded in public conversations about the extent and impact of workplace change throughout the West, and the "future of work" has also become a major policy concern (The Future of Jobs Report 2018, 2018).

In the U.S., Reinardy has previously focused, through interviews and surveys, on journalists who have remained in newsrooms depleted by layoffs and rapid changes in work practices over the course of the last decade (Reinardy 2011; Reinardy and Greenwood 2011; Reinardy and Bacon 2014). Significantly, his recent characterization of contemporary news workers as a "lost generation" (Reinardy 2017) included journalists who have remained in their roles as well as those who have departed (Lee 2016). Older journalists, he contends, feel a sense of loss because of changes in newsroom culture, burnout, and the requirement to become proficient in new technologies. Meanwhile young journalists entering newsrooms lack the direction and strong mentorship from older journalists that previously typified newsroom culture. These findings are broadly consistent with those of Nikunen's study of Finnish newsroom survivors, which found that "older journalists, particularly, struggled to hold on to their professional values and notions of expertise when, in practice, they had difficulties in bringing their expertise into use in the new technology-centered newsroom structure" (Nikunen 2014, 868).

But what of those who lose their jobs, whether through layoffs or forced terminations? The consequences that flow from forced career change have long been of interest to sociologists (see, for instance, Price, Friedland, and Vinokur 1998). As Brand notes in a recent review of sociological research into job loss (Brand 2015), "a job is more than a source of income. It is a fundamental social role and source of identity" (p. 370). The displacements that follow from losing jobs "are associated with subsequent unemployment, long-term earnings losses, and lower job quality; declines in psychological and physical well-being; loss of psychosocial assets; social withdrawal; family disruption; and lower levels of children's attainment and well-being" (Brand 2015, 359). She also notes that "while reemployment mitigates some of the negative effects of job loss, it does not eliminate them."

Social Identity Theory (SIT) proposes that as individuals associate with social groups, they develop a positive self-identity (Tajfel and Turner 1979). Self-esteem stems from association with social groups, and that association develops positive or negative values that contribute to a group's internal and external prestige (Tajfel and Turner 1986). Identities are comprised of personal identity and multiple social identities (Grubenmann and Meckel 2017). Several studies have demonstrated that social identities are exhibited in professions and occupations (Barley 1989; Trice 1993; Kreiner, Hollensbe, and Sheep 2006).

In defining social identity, Tajfel wrote that it is "the individual's knowledge that he (or she) belongs to certain social groups together with some emotional and value significance to him (or her) of this group membership" (Tajfel 1972, 292). 
It's common for American newspaper journalists to embrace their profession as more than the means to earn a paycheck. Buoyed by the First Amendment, news workers enter what has been described as a noble profession that lures men and women of high integrity committed to a journalism of social responsibility (Mott 1962; Weaver and Wilhoit 1996). Oftentimes, that social responsibility nurtures a professional identity that had traditionally sustained the longevity of an entire working career (Reinardy 2009).

Grubenmann and Meckel (2017) examined how changes in a newsroom altered the perceived identities of journalists taking on new roles. The authors suggest that social identity theory, particularly professional identity, is linked to journalist role concepts. They asked, "How does journalists' professional identity influence their perceptions and interpretations of the changes in their profession?" (Grubenmann and Meckel 2017, 733). Their study included Swiss journalists experiencing a transition to a converged newsroom, where two editorial teams were integrated. The online journalists were being integrated into existing print departments. The authors wrote: "By contrasting two groups' identity negotiation mechanisms in a Swiss newsroom, we illustrate how journalists' interpretations of change, of different core values of journalism, and their professional identities interplay in these days of 'mind-blowing uncertainty,'" (Grubenmann and Meckel 2017, 743).

There are a multitude of studies that examine identity and job loss. Losing a job also translates into losing a social role (Price, Friedland, and Vinokur 1998). Roles assist in developing an idea of self (Turner 1978; Callero 1992, 1994), and a loss of a role is a substantial challenge to an individual's identity (Price, Friedland, and Vinokur 1998). Job loss challenges identity and self-esteem by modifying friendships (Atkinson, Liem, and Liem 1986; Bolton and Oatley 1987) and social support (Kessler, Turner, and House 1988). Price, Friedland, and Vinokur (1998) wrote:

These identity interruptions are stressful, and the key to preventing their negative consequences is to allow a new identity to be affirmed. If people are able to negotiate new identities that are satisfactory, the negative effects of job loss may be minimized (p. 309).

Studies of the impact of job loss on laid off journalists remain relatively scant. Some of the earliest attempts to research the scale and implications of journalism job loss through surveys came from the U.S. and U.K., where the job losses in the 2008-9 period were especially severe, and, in global terms, ahead of the curve. In California, the San Francisco Bay Area Journalist Census 2000-2010, was a project of the North Valley Job Training Consortium, which conducted a one-off study measuring workforce dislocation among Bay Area journalists (The Natelson Dale Group and Group 2011). In the U.K., a 2010 study led by Francois Nel at the University of Central Lancashire surveyed 144 laid off journalists after a decade where up to a third of journalism jobs in the U.K. had disappeared (Nel and Journalism.co.uk 2010).

In Australia, there was initial optimism that the mass layoffs experienced in the U.S. (Brownlee and Beam 2012) and U.K. between 2008 and 2011 might be circumvented (Este et al. 2010). Between 2011 and 2018, up to a quarter of Australian journalists about 3,000 positions - are estimated to have been lost (Zion et al. 2018). The New Beats project has since been tracking the experiences of laid off journalists, beginning with a 2013 pilot study (O'Donnell, Zion, and Sherwood 2016), followed by a four-year longitudinal study that has surveyed journalists who were laid off between 2012 and 
2014, and each year from 2014 and 2017 to gain insight into how journalists have fared over time in terms of kinds of employment, income, well-being, attitudes to journalism, and changes to professional identity.

Key findings in the first of these surveys, which attracted 225 completed responses, revealed the extent of the contrast between the previous relative stability of Australian newsrooms that had been disrupted by a series of rounds of layoffs, and the extent to which the ranks of experienced journalists were being depleted (Zion et al. 2016).

With respect to re-employment, around $60 \%$ of the respondents said they were working, whether full or part time, in some form of journalism - including a mix of journalism and other work. Many of those who said they were now working outside of journalism were in roles such as strategic communication that deployed their journalism skills, and in certain cases - contacts. But only about $10 \%$ had moved into new full-time journalism roles. And while a majority reported that quality of life, as measured by factors including stress and work-life balance, had improved, "the process of job loss was highly unsettling and traumatic, exacerbated in many cases by a perception that management had handled the redundancy process poorly" (Zion et al. 2016, 121).

Another finding from the same survey data was that professional identity was likely to decline post-job loss (Sherwood and O'Donnell 2018) with more respondents describing their journalist identity as weak or fading (85 out of 122 respondents or $70 \%$ ) rather than intact (37 out of 122 respondents or $30 \%$ ). This aligns with Waisbord's model of journalistic professionalism (2013) which links journalistic professional identity to their work status rather than to an independent system of values. It should be noted, however, that about one-third of those who were no longer employed in journalism roles reported their journalistic identity as being intact (Sherwood and O'Donnell, p. 1032).

Building upon New Beats: A study of Australian Journalism Redundancies, the purpose of this study is to examine how job loss and possibly career loss among U.S. newspaper journalists has affected their professional identity and perceptions of newspaper journalism. This study examines the following research questions:

RQ1: What emotional and practical issues did U.S. newspaper journalists confront following their job loss or departure?

RQ2: How did re-employment in newspaper journalism affect the professional identity of U.S. journalists?

RQ3: How did re-employment in a job outside newspaper journalism affect the professional identity of former U.S. journalists?

RQ4: What is the overall perception of U.S. newspaper journalism among those who at some point lost their jobs in journalism?

\section{Methodology}

For this study, a 62-question survey was replicated from the New Beats project with a few modifications to make it more suitable for American journalists. For instance, the word "redundancy" - a term that refers to jobs that are terminated with compulsory termination payments made to the employee - was substituted to represent the nomenclature of job losses at U.S. newspapers. Accordingly, the Australian question, "Before you took 
redundancy, how many years of experience in journalism did you have?" was edited for the U.S. survey to read "Before you were laid off or took a buyout, how many years of experience in journalism did you have?"

Replicating the New Beats study, this study utilized snowball sampling (O'Donnell, Zion, and Sherwood 2016; Zion et al. 2016; Sherwood and O'Donnell 2018). The survey was distributed via snowball sampling, beginning with 24 journalists who had lost their newspaper jobs in the past seven years. Some had returned to newspapers since their original departure, and some had left the industry. They were asked to share the survey with former colleagues who had also left newspapers. The study also used a convenience sample with a post on the "What's Your Plan B?" Facebook page, which had 12,834 members when the survey was distributed in July 2018. "What's Your Plan B?" is a closed Facebook page for journalists who have been laid off or who are expecting to lose or leave their journalism jobs ("What's Your Plan B? Description," 2018).

The Qualtrics survey link was included in a "What's Your Plan B?" post in July 2018. An invitation describing the study with a link to the survey was posted two additional times on the Facebook page in two consecutive weeks. Additionally, an invitation that included the survey link was emailed to the 2,500-member American Copy Editors Society (ACES) group in July 2018. The email was distributed to the ACES group through the organization's leadership.

Replicating the structure of the 2014 New Beats Project survey, this survey's questions were divided into five sections: Newspaper Career; Buyout/Layoff Experience; Current Employment Status; Making Sense of Change; and Demographics.

The university's institutional review board approved the study, and as recommended by the IRB, the survey recipients were told participation was voluntary, and assured their responses would be confidential and only reported as part of group results.

\section{Results}

Depending upon the question, the number of participants who answered closed-ended questions ranged from 288 to 381 journalists. The number of respondents is reflective of similar studies that examined journalists who left their jobs. For instance, the 2014 New Beats Australian survey attracted 225 completed responses (Zion et al. 2016).

The respondents averaged 52 years old (ranged $=24-72$ ) and about 21 years of professional experience when they left their newspapers. About $54 \%$ of the respondents were female $(n=165), 94 \%$ Caucasian, and $96 \%$ had earned a four-year college degree, Master's degree or Ph.D. At the time of their departure, $95 \%$ were working full-time at their newspapers $(n=349)$, earning on average about $\$ 58,000$ annually (range $=$ $\$ 18,000-\$ 165,000)$. Of the 333 who left their jobs, about $41 \%$ decided to leave on their own without a buyout or being laid off ( $n=137), 33 \%$ were laid off, and $18 \%$ accepted a buyout. ${ }^{1}$ A large majority of journalists left their newspapers between 2008 and 2018 (82\%), with the most leaving in 2008 (12\%), followed by $2015(11 \%)$, and 2012 and 2017 (10\% each year).

Before leaving their newspapers, $51 \%(n=142)$ did not receive any digital training, while $29 \%$ received employer-funded training. When they returned to work, $45 \%$ were working in a non-journalism role $(n=125)$, as $12 \%$ were either working in journalism (including freelance work) or a mix of journalism and some other work (19\%). 
To address RQ1, which asks what emotional and practical issues U.S. newspaper journalists confronted following their job loss or departure, a content analysis was conducted of 272 responses to the open-ended statement, "Please tell us about the experience losing your job, including any emotional or practical issues encountered." Of the respondents, $39 \%$ said they experienced some emotional difficulty such as depression, sadness, devastation and heartbreak. Some of the depression was clinical, and two participants said they experienced post-traumatic stress. Twenty-four percent said they were "relieved," "happy," and "excited" following the job departure. The primary practical implication was financial with $18 \%$ saying personal finance and potential loss of household income was a concern (see Table 1).

The open-ended responses provided additional insights into the emotional and practical issues journalists encountered upon losing their jobs. Respondent 38, a 29-year-old female former editor and now a copywriter, represented many who expressed emotional difficulty in leaving their newspapers by writing: "It was heart-breaking to leave. This was my dream job and I absolutely loved being able to cover the community in the way that I did." Respondent 84, a 40-year-old male reporter with 10 years experience, wrote, "I was devastated to feel so expendable." A 52-year-old female online editor, respondent 232, wrote, in part, "I was devastated. Still am. My whole adult identity is tied to being a reporter, editor, writer, creator.... I lost my place in the world."

It wasn't all gloom and doom for the $21 \%$ who expressed a sense of relief in a career change outside newspapers. A 31-year-old female reporter, respondent 146, wrote: "Honestly, as soon as I walked out of the building, the depression I had been experiencing for about nine months before then lifted." Respondent 177, a 50-year-old female editor with 20 years experience, wrote: "It was one of the best decisions I ever made. Leaving newspapers opened up the world for me and made me realize how valuable my skills really are."

Among participants who lost their newspaper journalism jobs or left of their own accord, 31\% ( $n=103)$ returned to journalism, including freelance work. Of those participants, 62 responded to RQ2, which asks, "How did re-employment in newspaper journalism affect the professional identity of U.S. journalists?" About $24 \%$ said their professional identification changed but the specifics of the change were either title (i.e., copy editor to reporter) or a life change (Respondent 61, 39-year-old male editor: "I used to define a massive chunk of my identity as a newspaper guy. There's more balance to my life now.") Sixteen percent expressed pride in the journalism work they produced, and $16 \%$ said they feel a loss of identity from the kind of journalism they used to create (see Table 2). In the open-ended comments, representing those who continue to take pride in their work, Respondent 77, a 43-year-old male editor wrote: "I still feel proud to be a journo but this comes at a price."

Table 1. Emotional/practical issues following job loss.

\begin{tabular}{lr}
\hline Emotional difficulty (devastated; depression, etc.) & $39 \%$ \\
Relieved/happy (ready to move on; excited) & $24 \%$ \\
Loss of household income & $18 \%$ \\
Moved into retirement & $7 \%$ \\
Angry/hurt/betrayed & $4 \%$ \\
\hline$N=272$. &
\end{tabular}


Table 2. Professional ID among those who returned to journalism.

\begin{tabular}{ll}
\hline Identity changed (title or life change) & $24 \%$ \\
Expressed pride in their work & $16 \%$ \\
Loss of identity & $16 \%$ \\
Does not apply & $16 \%$ \\
No change & $10 \%$ \\
\hline$N=103$. &
\end{tabular}

Among those who left journalism, $72 \%$ were working full time and $12 \%$ were selfemployed. For participants working full time outside journalism, 40\% described jobs in communications, marketing and public relations. Of the overall sample, about $22 \%$ were working outside media completely, and $10 \%$ were working in education. Meanwhile, $26 \%$ in this section of the survey said they were working journalism-type jobs such as writer, copy editor, editor and graphic design (see Table 3).

In addressing RQ3 - how did re-employment in a job outside newspaper journalism affect the professional identity of former U.S. journalists - 137 participants responded to the statement, "Please tell us about how this career change affected your professional identity." Nearly half, $47 \%$, said the career change did not affect their professional identity. Meanwhile, $36 \%$ still identify themselves as journalists, although many have not worked in their traditional newspaper job for several years. Another $18 \%$ said they did not have any professional identity at all. In analyzing the open-ended comments, the most interesting participants were among the $36 \%$ who continued to identify themselves as journalists even though they admitted to no longer working in journalism. Respondent 104, a 37year-old female former editor who is now an innovation consultant, wrote: "I absolutely identified myself as a journalist first. Having that stripped away from me really made me question my value and purpose in life. It was a major ego blow." Respondent 97, a 48-year-old male senior editor who is now a content strategist, wrote, in part, "Being a reporter is one of those jobs, like police officer, doctor or lawyer, that can define a person even outside of work hours.... Being a content strategist does not wield the same mystique outside of certain circles."

RQ4 asked, "What is the overall perception of U.S. newspaper journalism among those who at some point lost their jobs in journalism?" To address the research question, the survey asked all respondents to "Please tell us how you feel about journalism today." Some respondents provided multiple answers, causing the total percentage to exceed 100. Of the 296 respondents, $26 \%$ said it was valuable, important work that is critical to the U.S. democracy. Twenty-six percent viewed it as noble work and were supportive of the journalists doing that work. Meanwhile, 29\% said newspaper journalism today was "dying," "dead," "diminished" and "disappointing." Another 22\% said they were saddened and "depressed" by the current state of American newspaper journalism (see Table 4). Representative of those who said journalism continues to be important to the U.S.

Table 3. Re-employment outside newspapers.

\begin{tabular}{ll}
\hline Communications/PR/Marketing & $40 \%$ \\
Writer/copy editor/editor/graphic design & $26 \%$ \\
Jobs outside media & $22 \%$ \\
Education & $10 \%$ \\
\hline$N=151$. &
\end{tabular}


Table 4. Perceptions of newspaper journalism today.

\begin{tabular}{lr}
\hline Dead/dying/diminished & $29 \%$ \\
Critical/important to democracy & $26 \%$ \\
Noble work/supportive of journalists & $26 \%$ \\
Sad/depressed by current state of journalism & $22 \%$ \\
Valuable but dying & $11 \%$ \\
\hline$N=296$. & \\
*Because respondents were allowed to provide multiple answers, the total exceeds $100 \%$.
\end{tabular}

democracy, Respondent 11, a 36-year-old male public affairs officer, wrote, "Overall, I have great respect for journalism, especially newspaper journalism as a noble industry vital to our democracy. It is sad especially to see so many cuts in local media jobs and the loss of local news sources." Respondent 230, a former business reporter and now a 37-year-old communications manager, wrote: "It's a hard business to be in, but a very important one. We (society) will miss them when they are gone."

The quality of today's journalism was another issue for $29 \%$ of the respondents. A 25 year-old female former copy editor who now works as a graphic designer outside journalism, Respondent 113, wrote, "I'm disappointed in it. I'm disappointed in the lack of respect for journalists from the general public and I'm disappointed in the quality difference of my former paper over the last few years."

Representing the thoughts of several respondents who said newspaper journalism is diminishing, Respondent 324, a 57-year-old female former staff writer who now works in media relations, wrote, in part, "The stories I see are superficial, biased and not well developed."

A 33-year-old male former web producer who no longer works in journalism, Respondent 236, wrote, "I wish the skills that were once valued - strong design, copy editing and writing - were still valued today. It's clear to me that they are not."

\section{Discussion}

While there are some differences between the composition of the respective cohorts ${ }^{2}$ of the Australian and American studies, the similarities are more salient. The results from this survey echo many of the findings of the 2014 New Beats Australian survey on which the questionnaire of this survey is based.

Demographically, the U.S. and Australian cohorts shared some common characteristics. In this survey, the average age of participants was 54; in Australia, it was 49. In both cases, respondents had left jobs after an average of more than two decades with the same company (Zion et al. 2016). Of even more significance was that in both the U.S. and Australian surveys, participants shared in considerable detail their experiences of moving from often long and stable careers as journalists to what were often more precarious and less financially rewarding forms of employment. Yet overall, journalists in both countries were able to find work, even if this was not full-time or as stable.

And as in the U.S., about $30 \%$ of Australian participants said they continued to work in journalism roles, including freelance, across all four annual surveys conducted by the New Beats team, but only about a third of these said that they were working in fulltime journalism positions (Zion et al. 2016, 2018). The finding in this paper that communications PR and marketing roles were a common destination for those who left 
journalism jobs in the U.S. (40\%) also echoes the Australian situation where $56 \%$ of those who moved outside of journalism went into such roles (Zion et al. 2016, 125-126). Similar to their American counterparts, Australians who were laid off or bought out also shared experiences of the process that referenced the full gamut of emotions (Ricketson et al. 2019).

Not surprisingly, this survey found that issues involving professional identity for those who have experienced job loss are extremely complex, and may at times seem contradictory, especially when those working outside of journalism continue to see themselves as journalists. But this response is also indicative of the transitional circumstances that play out in a number of ways when dealing with career transitions. One conclusion from an analysis of Australian survey findings is that:

the twin experiences of job loss and job seeking offer a productive vantage point on this dynamic relationship because they prompt journalists to consider not only their own job prospects but also the labor market for journalism skills, the chances of work outside journalism and the implications of these new opportunities for professional identity (Sherwood and O'Donnell 2018, 1022).

So while that 2014 Australian survey found that identify as journalists was weakened by departure from major media outlets, it also found that around a third of those who were no longer employed in journalism roles reported their journalistic identity as being intact (Sherwood and O'Donnell 2018, 1032).

A common finding, therefore, of both this study and the Australian parent study, is that journalists are actively negotiating their professional identity at a profoundly challenging moment, and that despite the role of structural forces, journalists are retaining at least some agency in how they define themselves $(2018,1035)$.

\section{Conclusion}

The purpose of this study was to gather data that would allow for an examination of how forced career change among U.S. newspaper journalists has affected their employment, professional identities, financial situations and perceptions of newspaper journalism. Drawing from a sample of about 350 former and current U.S. newspaper journalists who had lost or left their jobs, the study generated substantial data on the perceptions of both those who returned to newspapers following a departure and those who changed careers altogether.

As demonstrated in previous work, U.S. newspaper journalists - those who continue working in newspaper journalism and those who have moved into new jobs - have a complicated relationship with professional identity. Brand (2015) notes that a job provides more than financial stability and acts as "a fundamental social role and source of identity" (p. 370). The loss of a job can lead to a plethora of issues, including the loss of social status (Ezzy 1993), personal identity and self-esteem (Price, Friedland, and Vinokur 1998), all of which were prevalent in this study.

In defining social identity, Tajfel (1972) proposed that belonging to a specific social group enhances value and emotional significance as a group member. Losing a job, and in essence a social group, translates into losing a social role (Price, Friedland, and Vinokur 1998), and losing a social role is a substantial challenge to an individual's identity 
(Price, Friedland, and Vinokur 1998). Price, Friedland, and Vinokur (1998) said identity disruptions are stressful and can interfere with developing a new identity. But, if new identities are established, the negative consequences of job loss may be minimized (Price, Friedland, and Vinokur 1998).

In this study, nearly $40 \%$ of respondents said they experienced emotional and practical issues following the job loss, including depression, sadness, devastation and heartbreak. Of the $31 \%$ who returned to journalism, about a quarter said their professional identity changed, and $16 \%$ said they felt a loss of journalistic identity. Of those who were re-employed outside journalism, nearly half said the career change did not alter their professional identity. However, $36 \%$ still identified themselves as journalists, even though they no longer worked in journalism. Perhaps aligning with social identity theory, retaining the journalistic identity despite being removed from a journalism job could be a coping mechanism that continues to add social value and a sense of belonging for the individual. Perceived as a noble profession of high integrity (Mott 1962; Weaver and Wilhoit 1996), former journalists might be reluctant to forfeit an identity that has been carefully cultivated and deeply rooted for years and possibly decades of their professional and personal lives.

While we have noted some limitations in this study, including the possible issues of snowball sampling, the number of responses and the extent of participant responses to a mix of fixed and open-ended questions has demonstrated that in many respects American journalists who have left jobs - whether by choice or through the termination of their roles - have gone through a set of experiences broadly in line with those identified in the parent Australian study. Despite the broad range of answers to particular questions, the collective picture portrayed is of a group of professionals experiencing significant and disorientating transitions at a time when the stability and centrality of the newspaper newsroom has been disrupted by the collapse of the traditional business model.

The findings of this study complement and extend the research conducted on career change and burnout for those who remain in downsized newsrooms, while the extent to which the results echo the findings in Australian research on journalism job loss suggests that the issues confronted by participants in this survey can be seen to have a transnational dimension, notwithstanding the differences between the media ecologies of the two countries.

If this study is any indication, many of those who left journalism appear to have continued to embrace their former identities through a nostalgic lens. The questions that persist and are possible subjects for future research include the long-term implications that leaving their newspaper roles will have on their work identities and career trajectories.

Additionally, what becomes of the professional identities of those who remained in newspaper journalism but have been first-hand witnesses to its profound structural changes and diminished role in society? Is it better to leave with fond memories mostly in tact or to remain in the profession to witness its demise? For journalists who remain in journalism, it appears their identities continue to transform and possibly erode.

\section{Notes}

1. While this survey focused on newspaper journalists who were laid off or bought out or left of their own accord, the Australian New Beats survey on which this was modeled surveyed journalists from all platforms, but did not include those who left of their own accord without a buyout. 
2. For instance, the Australian New Beats survey on which this study was modeled surveyed journalists from all platforms, but did not include those who left of their own accord without a buyout.

\section{Disclosure Statement}

No potential conflict of interest was reported by the authors.

\section{Funding}

The authors received funding from the Australian Research Council for Linkage Project 140100341 (2014-2019) and Project grant DP150102675 (2015-2019) to conduct the research on which this article is based.

\section{References}

Atkinson, T., R. Liem, and J. Liem. 1986. "The Social Costs of Unemployment: Implications for Social Support." Journal of Health and Social Behavior 27: 317-331.

Barley, S. R. 1989. "Careers, Identities, and Institutions: The Legacy of the Chicago School of Sociology." In Handbook of Career Theory, edited by M. B. Arthur, D. T. Hall, and B. S. Lawrence, 41-65. Cambridge: Cambridge University Press.

Bolton, W., and K. Oatley. 1987. "A Longitudinal Study of Social Support and Depression in Unemployed Men." Psychological Medicine 17: 453-460.

Brand, J. E. 2015. "The Far-Reaching Impact of Job Loss and Unemployment." Annual Review of Sociology 41: 359-375.

Brownlee, B. J., and R. A. Beam. 2012. "US Journalists in the Tumultuous Early Years of the 21st Century." In The Global Journalist in the 21st Century, edited by D. Weaver, and L. Willnat, 348362. London: Routledge.

Callero, P. L. 1992. "The Meaning of Self-in-Role: A Modified Measure of Role-Identity." Social Forces 71 (2): 485-501.

Callero, P. L. 1994. "From Role-Playing to Role-Using: Understanding Role as Resource." Social Psychology Quarterly 57 (3): 228-243.

Conger, R. D., G. H. Elder, F. O. Lorenz, K. J. Conger, R. L. Simons, L. B. Whitbeck, and J. N. Melby. 1990. "Linking Economic Hardship to Marital Quality and Instability." Journal of Marriage and the Family 52: 643-656.

Este, J., C. Warren, F. Murphy, and M. Alliance. 2010. Life in the Clickstream II-The Future of Journalism. Sydney: Media Alliance/Walkley Foundation. http://www.thefutureofjournalism.org.au/wpcontent/uploads/life-in-the-clickstream.pdf.

Ezzy, D. 1993. "Unemployment and Mental Health: A Critical Review." Social Science \& Medicine 37 (1): 41-52.

Freud, S. 1930. Civilization and its Discontents. New York, NY: Jonathan Cape and Harrison Smith.

The Future of Jobs Report 2018. 2018. Geneva. https://www.weforum.org/reports/the-future-of-jobsreport-2018.

Grieco, E. 2018, July 30. Newsroom Employment Dropped Nearly a Quarter in Less Than 10 Years, with Greatest Decline at Newspapers. Pew Research Center. http://www.pewresearch.org/fact-tank/ 2018/07/30/newsroom-employment-dropped-nearly-a-quarter-in-less-than-10-years-withgreatest-decline-at-newspapers/.

Grubenmann, S., and M. Meckel. 2017. "Journalists' Professional Identity: A Resource to Cope with Change in the Industry?" Journalism Studies 18 (6): 732-748.

Kessler, R. C., J. B. Turner, and J. S. House. 1988. "Effects of Unemployment on Health in a Community Survey: Main, Modifying, and Mediating Effects." Journal of Social Issues 44 (4): 69-85. 
Kreiner, G. E., E. C. Hollensbe, and M. L. Sheep. 2006. "Where Is the 'Me' among the 'We'? Identity Work and the Search for Optimal Balance." Academy of Management Journal 49 (5): 1031-1057.

Lee, D. 2016. "What a Kansas Professor Learned after Interviewing a 'Lost Generation' of Journalists." Columbia Journalism Review, September 7. https://www.cjr.org/united_states_project/scott_ reinardy_journalisms_lost_generation_book.php.

Letts, S. 2016. "Global Internet Giants Crushing Australian Media." ABC News, January 29. http://www. abc.net.au/news/2016-01-29/global-internet-giants-crushing-australian-media/7125458.

Menaghan, E. G. 1991. "Work Experiences and Family Interaction Processes: The Long Reach of the Job?" Annual Review of Sociology 17: 419-444.

Mott, F. L. 1962. American Journalism: A History: 1690-1960. New York, NY: The McMillan Company.

The Natelson Dale Group, \& Group, T. N. D. 2011. Research Study of Workforce Disclocation among San Francisco Bay Area Journalists. San Francisco. http://www.novaworks.org/Portals/3/Nova/ Docs/LMI/JournalistDislocation_0411.pdf.

Nel, F. P., and Journalism.co.uk. 2010. Laid Off: What do UK Journalists do Next? http://www.scribd. com/doc/37088778/Laid-Off-What-Do-Journalists-Do-Next.

Nikunen, K. 2014. "Losing my Profession: Age, Experience and Expertise in the Changing Newsrooms." Journalism: Theory, Practice \& Criticism 15 (7): 868-888. doi:10.1177/1464884913508610.

O'Donnell, P., L. Zion, and M. Sherwood. 2016. "Where Do Journalists Go After Newsroom Job Cuts?" Journalism Practice 10 (1): 1-17. doi:10.1080/17512786.2015.1017400.

Price, R. H., D. S. Friedland, and A. D. Vinokur. 1998. "Job Loss: Hard Times and Eroded Identity." In Perspectives on Loss: A Sourcebook, edited by J. H. Harvey, 303-316. Philadelphia, PA: Taylor and Francis.

Reinardy, S. 2009. "Beyond Satisfaction: Journalists Doubt Career Intentions as Organizational Support Diminishes and job Satisfaction Declines." Atlantic Journal of Communication 17: 126-139.

Reinardy, S. 2011. "Journalism's Layoff Survivors Tap Resources to Remain Satisfied." Atlantic Journal of Communication 19 (5): 285-298. doi:10.1080/15456870.2011.623075.

Reinardy, S. 2017. Journalism's Lost Generation: The Un-Doing of U.S. Newspaper Newsrooms. New York, NY: Taylor and Francis.

Reinardy, S., and C. Bacon. 2014. "Feast and Famine? Local Television News Workers Expand the Offerings but say They are Hungry for Quality Journalism." Journal of Media Practice 15 (2): $133-$ 145. http://0-dx.doi.org.alpha2.latrobe.edu.au/10.1080/14682753.2014.960766.

Reinardy, S., and K. Greenwood. 2011. "Self-trained and Selfmotivated: Newspaper Photojournalists Strive for Quality during Technological Challenges." Visual Communication Quarterly 18 (3): 155166. .http://0-dx.doi.org.alpha2.latrobe.edu.au/10.1080/15551393.2011.599285.

Ricketson, M, A. Dodd, L. Zion, and M. Winarnita. 2019. “'Like Being Shot in the Face' or 'I'm Glad I'm Out': Journalists' Experiences of Job Loss in the Australian Media Industry 2012-2014." Journalism Studies. doi:10.1080/1461670X.2019.1627899.

Sherwood, M., and P. O'Donnell. 2018. "Once a Journalist, Always a Journalist? Industry Restructure, Job Loss and Professional Identity." Journalism Studies 19 (7): 1021-1038. doi:10.1080/1461670X. 2016.1249007.

Standard-Examiner staff. 2018. "Standard-Examiner recognized in Utah Journalism Awards." Standard-Examiner, June 15. https://www.standard.net/opinion/our-view/standard-examinerrecognized-in-utah-journalism-awards/article_f8f3854a-1cf7-5399-9b91-10e186570ab2.html.

Tajfel, H. 1972. "Social Categorization." In Introduction à la Psychologie Sociale 1, edited by Serge Moscovici, 272-302. Paris: Larouse.

Tajfel, H., and J. C. Turner. 1979. "An Integrative Theory of Intergroup Conflict." In The Social Psychology of Intergroup Relations, edited by W. G. Austin, and S. Worchel, 33-47. Monterey: Brooks-Cole.

Tajfel, H., and J. C. Turner. 1986. "The Social Identity Theory of Inter-Group Behavior." In Psychology of Intergroup Relations, edited by S. Worchel, and L. W. Austin, 7-24. Chicago: Nelson-Hall.

Thoits, P. A. 1991. "On Merging Identity Theory and Stress Research." Social Psychology Quarterly 54 (2): 101.

Trice, H. M. 1993. Occupational Subcultures in the Workplace. Ithaca, NY: ILR Press.

Turner, R. 1978. "The Role and the Person." American Journal of Sociology 84: 1-23. 
Waisbord, S. 2013. Reinventing Professionalism: Journalism and News in Global Perspective. Cambridge: Polity.

Weaver, D. H., and G. C. Wilhoit. 1996. The American Journalist in the 1990s: U.S. News People at the End of an Era. Mahwah, NJ: Lawrence Erlbaum Associates, Inc.

What's Your Plan B? Description. 2018, July 9. https://www.facebook.com/groups/1476343355941323/ search/?query=scott reinardy.

Zion, L., A. Dodd, M. Sherwood, P. O'Donnell, T. Marjoribanks, and M. Ricketson. 2016. "Working for Less: the Aftermath for Journalists Made Redundant in Australia between 2012 and 2014." Communication Research and Practice 2 (2): 117-136. doi:10.1080/22041451.2016.1185924.

Zion, L., M. Sherwood, P. O'Donnell, M. Ricketson, A. Dodd, and M. Winarnita. 2018. New Beats Report: Mass Redundancies and Career Change in Australian Journalism. doi:10.13140/RG.2.2.31714. 17606. 